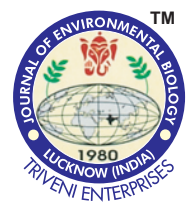

\title{
Progress in alternative antifouling technologies for healthy biodiversity
}

\section{Authors Info \\ H.W. Shin ${ }^{1 *}$, S.M. Jung1, H.J. Lee $^{1}$,T.H. Park', J.H. Yoon', K.S. $\mathrm{Lee}^{2}$, J.T. Kim ${ }^{3}$ and J. D. Lee \\ 'Department of Life Science and Biotechnology, Soonchunhyang University, 646 EupnaeRi, ShinchangMyun, Asan City, Choongnam Do, 336-745, South Korea ${ }^{2}$ Department of sports science, Soonchunhyang University, 646 EupnaeRi, ShinchangMyun, Asan City, Choongnam Do, 336-745, South Korea ${ }^{3}$ Department of Agriculutre, Fisheries, Livesstock and Economic committee, Jeju Special Self-Governing Provincial Council, Jeju, 63119, South Korea \\ ${ }^{4}$ Department of Environmental health science, Soonchunhyang University, 646 EupnaeRi, ShinchangMyun, Asan City, Choongnam Do, 336-745, South Korea}

*Corresponding Author Email : hwshin@sch.ac.kr

\section{Edited by \\ Professor Chae Woo Ma}

Reviewed by

Dr. Babita Paudel

Professor Sung June Jung

\section{Abstract}

In recent years the influx of tributyltin (TBT) pollutants in marine environment is of great concern. Antifouling (AF) coating release is considered as one of the major sources of TBT contamination. TBT is known to cause adverse negative impacts like bioaccumulation, proliferation of shell deformities, imposex etc. It has been well demonstrated that environmental TBT concentration lesser than $1 \mathrm{ngSn} \mathrm{f}^{-1}$ induces ill effects in several sensitive non-targeted marine living organisms. Besides, TBT accumulation in tissues of edible marine organisms and corresponding accumulation in humans is on the increase. Among the Asian countries, high frequency of imposex has been reported in Korea due to TBT toxicity. But survivorship of sensitive planktonic organisms is yet to be studied in detail. The existing local TBT restrictions and proposed international ban on TBT by International Marine Organization (IMO) has greatly helped in the restoration of growth and development of once severely suffered TBT sensitive organisms. In some instances, it was also related to 'green tide' by a hypothesis that the over growth of green algal communities has resulted due to TBT ban. Although Asian countries are major marine aquaculture producers, comparatively lesser initiatives have been incorporated in their national policies to combat TBT usage. It appears that this may be largely due to cost-effectiveness, as TBT coatings have long lasting effects. Many of the available alternative AF technologies are comparatively less effective and not suitable for broad-spectrum applications. In general, short longevity and cost-effectiveness are also a major drawback in alternatives. However, research attempts directed AF compounds extracted from marine natural products exhibit effective AF activity against 'monospecific' foulers. Allelopathic natural deterrent principles involved in these compounds have proved to be an eco-friendly AF technology. Our experimental investigations show that few Korean marine algae have broad-spectrum AF activity par with TBT. From the lessons learnt by many developed countries with regard to TBT crisis and alarming levels of TBT residues persisting in the Asian waters appropriate changes to be made in TBT restriction policies are discussed. Based on the revelations, suggestions were also made for effective means of controlling fouling organisms and to chalk out concrete action plans to check the ever increasing TBT contamination in the Asian waters.

\section{Key Words: Algae, Antifouling, Fouling organisms, Imposex, Trybutylin contamination}

How to cite : Shin, H.W., S.M. Jung, H.J. Lee, T.H. Park, J.H. Yoon, K.S. Lee, J.T. Kim and J.D. Lee: Progress in alternative antifouling technologies for healthy biodiversity. J. Environ. Biol., 40, 977-982 (2019). DOI : http://doi.org/10.22438/jeb/40/5(SI)/SI-15 


\section{Introduction}

Biofouling is a natural phenomenon that affects all maritime technologies. Surfaces exposed to seawater immediately adsorb dissolved organic compounds thereby forms a "conditioning film". These surfaces are then colonized by more diversified group of microscopic bacteria, diatoms, fungi and protozoa. At this immobilized state (on the conditioning film) these primary fouler grow vigorously and develop a thick slime that is considered as prerequisite for the attachment of macro-algal spores and larval stages of macro-fouling communities. High reproductive potential of marine algae in particular Ulva spp and Enteromorphaspp enable them to attach rapidly and grow on ship hulls (Shin, 1995). The nutritive micro-fouling slime promotes subsequent settlement and metamorphosis of algal and animal foulers of the climax community. According to an estimate the worldwide cost involved in control of biofouling in shipping industries alone was estimated to be more than 1000 million US \$ annually. Attachment of sedentary fouling organisms onto ship hull increases the frictional resistance and it hampers the speed of ship, which on the other hand increases the fuel costs. Onemicron increase in hull roughness is same as fuel consumptions by $1 \%$ (Wilson and Hansson, 2015). On even moderately fouled vessel, mean roughness can exceed $100 \mathrm{~cm}$ (Townsin, 2003). This corresponds to more than $6 \%$ increase in fuel consumption (Bowden and Taylor, 1980). Schultz (2007) conducted experiments with a US Naval vessel and described that after removal of biofilm, as much as $18 \%$ less power was needed to maintain a given speed, maximum speed increased 1 knot (1.85 $\mathrm{km} \mathrm{hr}^{-1}$ ). Fouling on permanent man-made underwater structures (permanent harbor structures, piping systems, offshore rings, moored oceanographic instruments etc.) cause increase in hydrodynamic load and it also masking the underwater inspection. Furthermore, biofouling also accelerates biocorrosion on many of these unprotected surfaces. Biofouling pose several problems in the marine environment thus application of effective AF chemical is inevitable to avoid economic loss.

A superior broad-spectrum antifouling activity (AF) of tributyltin (TBT) was first recognized in late 60's, thereafter its application was spread all over the world within the short span of 10-20 years. Since then TBT is considered as a potential AF agent because of its guaranteed fouling protection and long lasting nature (about 5-7 years). The 'France experience' in the Arcachon Bay located in the French Atlantic first recognized the negative impacts of TBT (Alzieu et al., 1986). Excessive TBT concentration in the coastal waters severely affected the oyster production from 1975-1982. The French National TBT Restriction Policy adopted in 1982 controlled the indiscriminate usage of TBT. According to this ban, use of AF paints containing TBT on boats less than $25 \mathrm{~m}$ long was prohibited. Hence, TBT contamination from smaller fishery and recreational boats anchored in the shallow coastal waters was identified as a major source that affected the coastal oyster species. Followed by these early TBT restrictions in the
French waters, there has been a sign of recovery in oyster farming and also in reduced rate of shell deformities in shellfishes. After the proliferation of TBT contamination around the world and its negative impacts recognized, during 1989-1992 many countries invariably included TBT restrictions in their marine pollution policies. However, the degree and enforcement of restrictions showed many variations as a result of influence from other local policies, which are only considering the monitory benefit of TBT applications. In other words, we can say that TBT was successfully marketed in many countries utilizing the loopholes in the local policies

Subsequently, considering the negative impacts of TBT and well- recognized 'French experience', ban for less than $25 \mathrm{~m}$ long boats was implemented in the UK, USA, The Netherlands, Switzerland, New Zealand, Japan and in the European Union. In 1999, a resolution passed by the Marine Environmental Protection Committee (MEPC) to ban TBT, and it was approved by the International Marine Organization (IMO) to propose a global ban from $1^{\text {st }}$ January 2003 for the application of TBT based AF paints, followed by a complete ban for using TBT from $1^{\text {st }}$ January 2008.

Even though many of the Asian countries are major producers of fishery and aquaculture products, TBT contamination and its negative impacts on marine living organisms were recognized in the late 80 's. Among the Asian countries, Japan took early initiatives to control TBT contamination in the late 80's (Harinoet al., 1998). However, in several Asian countries still TBT concentrations were reported in alarming levels including Japan (Horiguchi et al., 1998). On comparing the concentration of TBT in seawater, sediment and tissue, it appears that prevailing TBT concentration was high enough to cause adverse effects on marine living organisms.

TBT induces imposex in shellfish communities, mainly in gastropods in which male characters like penis and vas deferens are super imposed onto the female's genitalia. In extreme conditions, this dramatic effect leads to total sterility in TBT affected female population. Environmental concentrations of TBT as low as $1 \mathrm{ng} \mathrm{I}^{-1}$ has been reported to induce imposex in shellfishes (Ellis and Pattisina, 1990). Hence, reproductive impairment and frequency of imposex is considered as a criteria to measure the level of TBT concentration in the marine environment. TBT stunned the growth of shellfishes and induce deformities in shell formation with stacked chambers filled with gelatinous substances. Effects of butyltin compounds on marine biota are shown in Table 1. As shown in Table 1, crustaceans and mollusks species are more sensitive to TBT toxicity.Whereas fishes have been found to thrive in relatively high concentrations of TBT, followed by some species of algae. For comparison, no observed effects levels (NOEL) described for some sensitive organisms (Alzieu, 2000) have been tabulated (Table 1) to show high risk of persisting trend of TBT contamination in Asian countries. 
Table 1 : Effects of butyltin compounds on the marine biota, microalgae

\begin{tabular}{|c|c|c|c|c|c|}
\hline Organism & Response & TBT compound & Conc. $\left(\mu \mathrm{gl}^{-1}\right)$ & NOEL & References \\
\hline Skeletonema costatum & LC $100(5 d)$ & TВTO & 18.00 & $<\left.1 \mu g\right|^{-1}$ & Thain, 1983 \\
\hline " & EC $50(72 h)$ & TBTO & 0.33 & $<1 \mu \mathrm{gl}^{-1}$ & Walsh et al., 1985 \\
\hline Pavlova lutheri & LC100 (48h) & TBTO & 5.00 & $<1 \mu \mathrm{gl}^{-1}$ & Beaumont and Newman, 1986 \\
\hline Dunaliella tertiolecta & LC100 (48h) & TBTO & 5.00 & $<\left.1 \mu g\right|^{-1}$ & 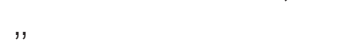 \\
\hline Skeletonema costatum & LC100 (48h) & TBTO & 5.00 & $<1 \mu \mathrm{gl}^{-1}$ & 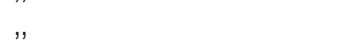 \\
\hline Chlorella vulgaris & $\operatorname{EC} 50(5 d)$ & TBTO & 130.0 & $<1 \mu \mathrm{gl}^{-1}$ & "Tsang et al., 1997 \\
\hline C. pyrenoidosa & " & TBT & 33.0 & $<1 \mu \mathrm{gl}^{-1}$ & $"$ \\
\hline Dunaliella tertiolecta & $"$ &, & 3.0 & $<1 \mu \mathrm{gl}^{-1}$ & , \\
\hline Spirulina subsalsa & IC 50 (8d) & " & 5.09 & $<1 \mu \mathrm{gl}^{-1}$ & "Chen etal., 1998 \\
\hline Nannochloropsis oculata & EC 50 (24h) & TBT & $0.29^{*}$ & $<1 \mu \mathrm{I}^{-1}$ & Sidharthan et al., 2002 \\
\hline
\end{tabular}

$\mathrm{LC}=$ Lethal Concentration, $\mathrm{EC}=$ Effectiveness Concentration, $\mathrm{TBTO}=$ Tributyltin oxide

Table 2: Effects of butyltin compounds on the crustaceans

\begin{tabular}{llllll}
\hline Organism & Response & TBT compound & Conc. $\left(\mu \mathrm{g} \mathrm{I}^{-1}\right)$ & NOEL & References \\
\hline $\begin{array}{l}\text { Daphnia magna } \\
\text { Gammarus oceanicus }\end{array}$ & $\mathrm{LC}_{50}(48 \mathrm{~h})$ & TBTO & & $<1 \mu \mathrm{gl}^{-1}$ & Plum, 1981 \\
\hline
\end{tabular}

Table 3 : Effects of butyltin compounds on molluscs

\begin{tabular}{|c|c|c|c|c|c|}
\hline Organism & Response & TBT compound & Conc. $\left(\mu g^{-1}\right)$ & NOEL & References \\
\hline Mytilus edulis & Growth Reduction (7wk) & TBT & 0.24 & $<2 \mathrm{ngl}^{-1}$ & Thainand Waldock, 1985 \\
\hline Crassostrea virginica & LD 100 (48-96h) & TBT & 1.00 & $<2 \mathrm{ngl}^{-1}$ & USEPA, 1985 \\
\hline Nucella lapillus & Imposex & TBT & 0.02 & $<2 \mathrm{ngl}^{-1}$ & Gibbs and Bryan, 1986 \\
\hline Crassostreagigas & Shell deformity & TBTO & 0.24 & $<2 \mathrm{ngl}^{-1}$ & Lawler and Aldrich, 1987 \\
\hline Mytilus edulis & LC $50(24 h)$ & TBT & 5.44 & $<2 \mathrm{ngl}^{-1}$ & Jha et al., 2000 \\
\hline Mytilus edulis & EC 50 (24h) & TBT & $0.62^{*}$ & $<2 \mathrm{ngl}^{-1}$ & Stenalt etal., 1998 \\
\hline
\end{tabular}

The incidence and frequency of imposex reported from some Asian countries are given in Table 2. In countries such as Japan, Korea and Thailand, 100\% imposex frequency was reported from several sampling localities in the coastal regions (Hiashiyamaet al., 1991; Hong et al., 2002; Bech, 2002). It appears that sampling sites located near inner harbor showed relatively high incidence of imposex as a result of TBT leached from boat hulls. TBT traces in marine living organisms reported from Asia-Pacific countries are given in Table 3. In general ,TBT concentrations were relatively high in samples from Korea, Thailand and Japan. A high value of $885 \mathrm{ng} \mathrm{l}^{-1}$ TBT was estimated from oyster samples collected from Chinhae bay, Korea (Hwang et al., 1999), minimum concentration were reported from Port Moresby, Papua New Guinea followed by samples from Vietnam. Whereas moderate TBT concentrations were reported in the samples collected from Sri Lanka, Hong Kong, Malaysia, Taiwan and India (Chiu et al., 1991; Guruge and Tanabe, 2001; Liu et al., 1997;Bhosle et al., 2004). TBT was excessively found to accumulate in filter feeding shellfish species when compared with prawn and fish species. TBT estimates shown in Table 2-3 are largely due to indiscriminate use of AF paints containing TBT.
Among Asian countries in marine mammals of Japanese coastal waters, butyltin compounds accumulated in high concentrations (Ohji et al., 2006). They also suggested that TBT concentrations in marine mammals of developed nations were relatively higher when compared with those of developing countries. Okoroet al. (2011) reported the accumulation of TBT in humans and wild terrestrial mammals in Japan. These studies clearly indicate the transfer of butyltin contamination from lower marine living organisms to higher trophic levels.

Alternative Technologies : Phenolic compounds are known to be a chemical deterrent present in variety of marine organisms that protects from grazing or epiphytic growth. Some phenolic acids have shown to possess potential antifouling properties. AF activity of phenolic acids such as sulphate-coumaric acid, transcinnamic acid, hydroxy benzoic acid, sodium p-n-pentyl phenyl sulphate, octanesulfonic acid-sodium salt and octylsulphate were screened against spore settlement of a fouling Chlorophyte, Ulva fasciata, in which trans-cinnamic acid and benzoic acid exhibited significantAF activity (Shin and Smith, 2001)equations.

Marine natural products have also been implicated for novel bioactive compounds. Some of these secondary 
Table 4 : Effects of butyltin compounds on fish

\begin{tabular}{|c|c|c|c|c|c|}
\hline Organism & Response & TBT compound & Conc. $\left(\mu \mathrm{gl}^{-1}\right)$ & NOEL & References \\
\hline Cyprinodon variegatus & $\operatorname{LC} 50(7 \mathrm{~d})$ & TВTO & 5.00 & $1-100 \mu g^{-1}$ & Ward et al., 1981 \\
\hline Salmo gairdneri & Growth Reduction & TBTCl & $0.20-1.0$ & $1-100 \mu \mathrm{gl}^{-1}$ & Seinen et al. (1981) \\
\hline Soleasolea & LC $50(48 h)$ & TBTO & 8.80 & $1-100 \mu \mathrm{gl}^{-1}$ & Thain, (1983) \\
\hline Cyprinodonvariegatus & LC $50(7 d)$ & TВTO & 5.00 & $1-100 \mu \mathrm{gl}^{-1}$ & Ward etal., (1981) \\
\hline
\end{tabular}

Table 5 : Effects of butyltin compounds on the mammals and humans

\begin{tabular}{|c|c|c|c|c|c|}
\hline Country & Location & Organism/nature of sample & Year & TBT Conc.ng g ${ }^{-1}$ wet wt. & References \\
\hline Japan & Seto Inland Sea & Neophocaena asiaeorientalis & 1985 & 1100 & Iwata et al., 1995 \\
\hline$"$ & Taiji & Tursiops truncatus & 1986 & $254-287$ & Tanabe et al., 1998 \\
\hline$"$ & Off Sariku & Phocoenoides dalli & 1995 & $110-310$ & Takahashi etal., 1999 \\
\hline China & Dongshan & Neophocaena asiaeorientalis & $1990-91$ & $57-130$ & Tanabe et al., 1998 \\
\hline, & Lusi & " & 1991 & $42-93$ & " \\
\hline Philippines & Sulu Sea & Stenella longirostris & 1996 & $19-23$ &, \\
\hline$"$ &, & Lagenodelphis hosei & $"$ & $21-31$ & $"$ \\
\hline India & Bay of Bengal & Sousa chinensis & 1988-92 & $34-100$ & $"$ \\
\hline, & $"$ & Stenella longirostris & $"$ & $110-310$ &, \\
\hline Poland & $n=9$ & Human Liver & & $2.4-11.0$ & Kannan and Falandysz, 1997 \\
\hline Japan & $n=4$ &, & & $59-96$ & Takahashi etal., 1999 \\
\hline Denmark & $n=18$ &, & & $0.8-28.3$ & Nielsen and trand, 2002 \\
\hline
\end{tabular}

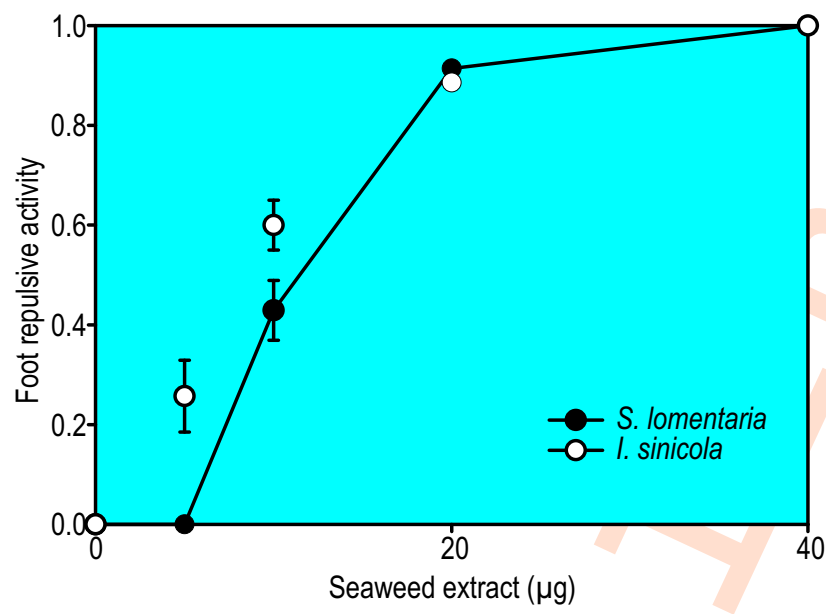

Fig. 1 : Mussel-foot repulsive activity by Ishigesinicola and Scytosiphon lomentaria.

metabolites have efficient AF activity. In an attempt to characterize the AF activity in Korean seaweeds, an extensive investigation was under taken from 1998 to 2001. A total of 220 species of macrophytes occurring along the Korean coast were screened for their AF efficiency. Preliminary antibacterial bioassays confirmed the consistent AF activity in 27 species (Chlorophytes 4; Phaeophytes 13; and Rhodophytes 10) (Cho et al., 2001). These seaweed species were further studied in detail with several assays to determine their effect on spore attachment and germination of a fouling alga, Enteromorphaprolifera . AF activity on foot repulsive response in Mytilus edulis was also investigated. Two Phaeophytes, Ishigesinicola and

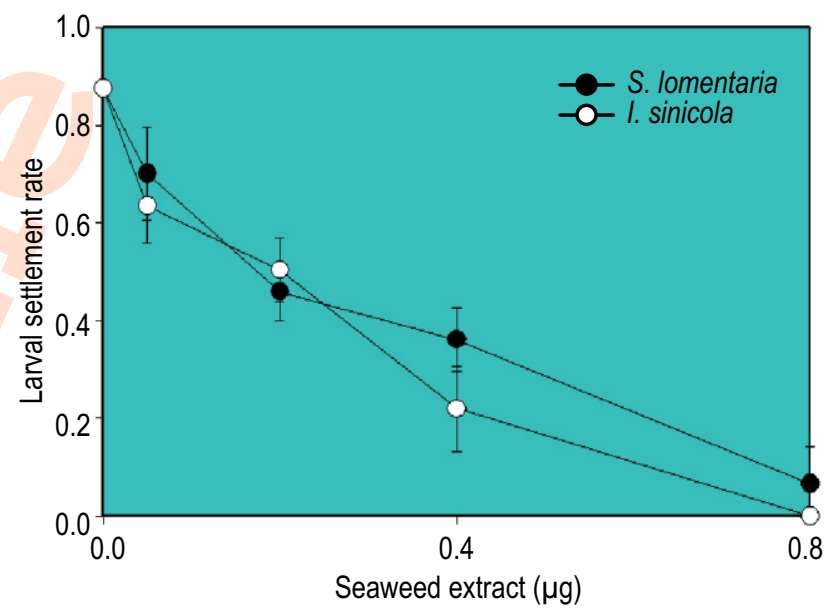

Fig. 2 : Ishigesinicola and Scytosiphon lomentaria. Effect on mussellarval attachment.

Scytosiphonlomentaria showed promising AF activity in spore assays and foot repulsion reaction, and they were also subjected to larval foot repulsion and settlement assay (Fig. 1 and 2). Extracts of $I$. sinicola and $S$. lomentaria prevented the larval settlement of M. edulis to 94 and $100 \%$, respectively (Fig. 2). The structural elucidation of promising AF substances isolated from these two seaweeds was analyzed by GC-Mass.

Test panel studies were conducted to determine AF efficiency of some selected seaweed extracts along with a sea grass extract. Two commercial AF coatings available in the local market and TBT were used for comparison. After 6 months 
exposure at Ayajin Harbor, east coast of Korea, fouling coverage on each test panel was estimated. Five major groups of fouling organisms were encountered. A cosmopolitan- fouling alga Ulva spp. was dominant in all the panels with fouling coverage ranging from 18.45 to $69.83 \%$. Low percentage coverage of 28.07 was estimated from /shige okamurae.

It is interesting to note that tunicates were abundant on toxic TBT and other commercial AF coating. The overall performance of $I$. okamurae showed promising AF activity with specific activity against tunicates. It is clear that some of the Korean seaweeds have specific AF activity against major fouling organisms. This can be exploited as an environmentally benign non-toxic AF coating.

In a dynamic membrane perfusion device designed to determine the minimum effective release rates (MERR) of TBT and zosteric acid at Snug harbor, Hawaii (Haslbeck et al., 1996), comparatively much higher release rate of $500 \mu \mathrm{g} \mathrm{cm}^{-2} \mathrm{~d}^{-1}$ was determined to prevent $50 \%$ of barnacle fouling (Table 5 ). Further, field experiments were also extended to evaluate the MERR for two phenolic acids, zosteric acid and coumaric acid. A $10 \mu \mathrm{g} \mathrm{cm}^{-2}$ $d^{-1}$ of MERRA was found to prevent $50 \%$ larval settlement at Ford Island, Hawaii (Shin et al., 2001) whereas coumaric acid showed a maximum of $31 \%$ reduction in the larval attachment of Hydroideselegans at Snug harbor, Hawaii (Shin and Smith, 2002) (Table 5).

\section{Discussion}

In the recent past, the cumulative effect of TBT ban has reduced substantial amount of organotin contamination largely in U.K, U.S.A and Europe and to a lesser extent globally (Sousa et al., 2013). The existing trend of TBT contamination in Asian countries is high enough to cause deleterious effects badly affected other regions of the world (Lau, 1991; Ko et al., 1995; Shim et al., 1998; Hung et al., 1998). Densely populated Asian countries having proportionately high consumption of sea foods in their diets are under high risk of excessive TBT ingestion (Kanna et al., 1995). As a major producers and exporters of seafood, it is mandatory for Asian countries to protect the marine environment from highly toxic pollutants like TBT as these anthropogenic pollutants are found to accumulate with high bioconcentration factors (Tanabe et al., 1998). Furthermore, the movement of TBT coated larger foreign vessels may be a potential source of TBT contamination in the territorial waters of a TBT banned country.

High concentration of TBT in waste released from dockyard is well known. Suitable technologies have to be developed to minimize the release of toxic AF waste from dockyard. Avery high concentration of TBT residues was reported from ship breaking sites of few Asian countries due to poor waste disposal management (Hossain et al., 2006).
Since harbors are indirectly served as sink for various pollutants, highly toxic TBT should be monitored closely as it is accumulated in the organic portion of the sediments at deleterious concentrations. Influx of TBT contamination from sources other than AF coatings is also given importance for the complete elimination. The alternatives should be efficient and parallel to TBT in preventing the fouling growth. On the other hand, less efficient alternative may allow a minimum fouling growth, which can increase the fuel consumption. Less life span of new alternatives may increase the frequency of docking of vessels for maintenance (Vázquez-Rowe et al., 2010). Jung et al., (2017) reported that nine alternatives such as irgaol 1051, diuron, chlrothalonil, dichlofluanid, sea-nine 211, copper pyrithione, zinc phrithion, ziram and zineb showed antifouling activity against microalgae Nitzschiapungens and zooplankton Artemia larvae for limitation time in $96 \mathrm{hr}$. Moreover, the cost of few long lasting AF coatings available in the market is 3-4 times high.

In case, the implementation of proposed IMO ban on TBT is extended for some time, further increase of existing ' $25 \mathrm{~m}$ ' length class mentioned for recreational and fishing boats should be considered. At least vessels owned by government agencies usage of non-toxic coatings may be encouraged by all means through related regulations.

Phasing out TBT is only possible after identifying an alternative AF technology having long lasting efficiency with broad-spectrum applications, irrespective of cost effectiveness for certain extent. Because up to $10 \%$ excess in AF coating cost can be realized as a tax hike. If the differences in excess increases more than $20 \%$ cost of the existing TBT based coatings, it may be difficult for the complete change over, especially in the international market. AF coating production is a highly competitive market. Any success in alternative technology may immediately recognize by the international companies. In this way, AF paint producers commitment to introduce the new AF coating will be helpful to mitigate the problem arising from AF coatings.

APEC recognized the seriousness for invasive aquatic species transferred through biofouling to cause harm (Olympia, 2017). APEC may mobilize grants to carryout research investigations to closely monitor the marine environmental pollution caused by antifoulants and search for the effective nontoxic AF chemical in developing countries. APEC should motivate non-member countries to extend the ban; this may be an important step towards global environmental safety.

\section{Acknowledgment}

This work was supported by a research fund from the Soonchunhyang University and Ministry of Environment.

\section{References}

Alzieu, C.L., J. Sanjuan, J.P. Deltreil and M. Borel: Tin contamination in Archachon Bay: Effects on oyster shell anomalies. Mar. Poll. Bull., 
17, 494-498 (1986).

Alzieu, C.: Environmental impact of TBT: The French experience. Sci. Total Environ., 258, 99-102 (2000).

Bowden, R.D., I.E. Heeson and J.M. Taylor: An approach to the evaluation of antifouling toxins II-results. In: Biodeterioration. Proceedings of Fourth International Biodeterioration Symposium, Berlin. Pitman Publishing, Vol. 1978, p. 297 (1980).

Bech, M.: Imposex and tributyltin contamination as a consequence of the establishment of a marina and increasing yachting activities at Phuket Island, Thailand. Environ. Pollut.,117, 421-429 (2002).

Bhosle, N.B., A. Garg, S.Jadhav, R. Harjee, S.S. Sawant, K. Venkat and A.C. Anil: Butyltins in water, biofilm, animals and sediments of the west coast of India. Chemosphere, 57, 897-907 (2004).

Chiu, S.T., L.M. Ho and P.S. Wong: TBT contamination in Hong Kong waters. Mar. Poll. Bull., 22, 220 (1991).

Chen, T.Y., Z.H. Song and L.S. Shen: Toxicity of tributyltin to Spirulina subsalsa. J. Environ. Sci. (China).19, 87-88 (1998).

Cho, J.Y., E.H. Kwon, J.S. Choi, S.Y. Hong, H.W. Shin and Y.K. Hong: Antifouling activity of seaweed extracts on the green alga Enteromorpha prolifera and the mussel Mytilus edulis. J. Appl. Phycol., 13, 117-125(2001).

Ellis, D.V. and L.A. Pattisina: Widespread neogastropodimposex: A biological indicator of global TBT contamination?. Mar. Poll. Bull., 21, 248-253 (1990).

Gibbs, P.E. and G.W. Bryan: Reproductive failure in population of the Dog-whelk Nucella lapillus, Caused by imposex induced by tributyltin from Antifouling Paints, J. Mar. Biol. Assoc. U.K., 66, 767777 (1986).

Guruge, K.S. and S. Tanabe: Contamination by persistent organochlorine and butyltin compounds in the west coast of Sri Lanka. Mar. Poll. Bull., 42, 179-186 (2001).

Hiashiyama, T., H. Shiraishi, A. Otsuki and S. Hashimoto: Concentrations of organotin compounds in blue mussels from the wharves of Tokyo Bay. Mar. Poll. Bull., 22, 585-587 (1991).

Haslbeck, E.G., C.J. Kavanagh, H.W. Shin, W.C. Banta, P. Song and G.I. Loeb: Minimum effective release rate of antifoulants: (2) Measurement of the effect of TBT and zosteric acid on hard fouling. Biofouling, 10, 175-186(1996).

Harino, H., M. Fukusima, Y. Yamamoto, S. Kawai and N. Miyazaki: Contamination of butyltin and phenyltin compounds in the marine environment of Otsuchi Bay, Japan. Environ. Pollut., 101, 209-214 (1998).

Horiguchi, T., C. Hyeon-SEO, H. Shiraishi, Y. Shibata, M. Soma, M. Morita and M. Shimizu: Field studies on imposex and organotin accumulation in the rock shell, Thais clavigera, from the Seto Inland Sea and the Sanriku region, Japan. Sci. Total Environ., 214, 65-70 (1998).

Hwang, H.M., J.R. Oh, S.H. Kahng and K.W. Lee: Tributyltin compounds in mussel, oysters and sediments of Chinhae Bay, Korea. Mar. Environ. Res., 47, 61-70 (1999).

Hong, H.K., S. Takahashi, B.Y. Min and S. Tanabe: Butyltin residues in blue mussel (Mytilus edulis) and arkshells (Scapharcabroughtonii) collected from Korean coastal waters. Environ. Pollut., 117, 475486 (2002).

Hossain, M.M.M. and M.M. Islam: Ship breaking activities and its impact on the coastal zone of Chittagong, Bangladesh: Towards sustainable management. Chittagong, Bangladesh: Advocacy and Publication Unit, Young Power in Social Action (YPSA)(2006).
Hung, T.C., T.Y. Lee and T.F. Liao: Determination of butyltins and phenyltins in oysters and fishes from Taiwan coastal waters. Environ. Pollut., 102, 197-203 (1998).

Jung, S.M., J.S. Bae, S.G. Kang, J.S. Son, J.H. Jeon, H.J. Lee, J.Y. Jeon, M. Sidharthan, S.H. Ryu and H.W. Shin: Acute toxicity of organic antifouling biocides to phytoplankton Nitzschiapungens and zooplankton Artemia larvae. Mar. poll. Bull., 124, 811-818(2017).

Kannan, K., S. Tanabe, H. Iwata and Tatsukawa: Butyltins in muscle and liver of fish collected from certain Asian and Oceanian countries. Environ. Pollut., 90, 279-195 (1995).

Ko, M.M.C., G.C. Bradley, A.H. Neller and M.J. Broom: Tributyltin contamination of marine sediments of Hong Kong. Mar. Pollut. Bull., 31, 249-253 (1995).

Lau, M.M: Tributyltin antifoulings: A threat to the Hong Kong marine environment. Arch. Environ. Contam. Toxicol., 20, 299-304 (1991).

Liu, L.L., S.J. Chen, W.Y. Peng and J.J. Hung: Organotin concentrations in three intertidal neogastropods from the coastal waters of Taiwan. Environ. Pollut., 98, 113-118, (1997).

Ohji, M., H. Harino and T. Arai: Differences in organotin accumulation among ecological migratory types of the Japanese eel Anguilla japonica. Estuar. Coast. Shelf Sci.,69, 270-290 (2006).

Okoro, H.K., O.S. Fatoki, F.A. Adekola, B.J. Ximba, R.G. Snyman and B. Opeolu: Human exposure, biomarkers and fate of organotins in the environment. In Reviews of Environmental Contamination and Toxicology Volume, Springer, New York, 213, $27-54$ (2011).

Olympia, W.: Washington state vessel-related biofouling management 6years strategic plan (2017).

Shim, W.J, J.R. Oh, S.H. Kahng and S.H. Lee: Accumulation of tributyland triphenyltin compounds in pacific oyster, Crassostreagigas, from the Chinhae Bay System, Korea. Arch. Environ. Contam.T oxicol., 35, 41-47 (1998).

Shin, H.W.: Biofouling by marine weedy algae. Algae, 10, 97-108 (1995).

Shin, H.W. and C.S. Smith: Antifouling activity of six nontoxic chemicals on spore attachment of Ulva fasciata. J. Environ. Biol., 22, 145-151 (2001).

Shin, H.W., C.S. Smith and E.G. Haslbeck: Minimum effective release rate of antifoulant, 1. Effects of Zosteric acid at Ford Island, Hawaii.(USA). J. Environ. Biol., 22, 243-250 (2001).

Shin, H.W. and C.S. Smith: Minimum effective release rate of antifoulants. 2. Effects of TBTCl, 2-furyl-n-pentyl ketone and coumaric acid at Snug harbour, Hawaii. J. Environ. Biol., 23, 71-75 (2002).

Schultz, M.P.: Effects of coating roughness and biofouling on ship resistance and powering. Biofouling, 23, 331-341 (2007).

Sousa, A.C., M.R. Pastorinho, S.Takahashi and S. Tanabe: History on organotin compounds, from snails to humans. Environ. Chem. Lett., 12, 117-137(2014).

Tanabe, S., M. Prudente, T. Mizuno, J. Hasegawa, H. Iwata and N. Miyazaki: Butyltin contamination in marine mammals from North Pacific and Asian coastal waters. Environ. Sci. Technol., 32,193-198 (1998).

Townsin, R.L.: The ship hull fouling penalty. Biofouling, 19, 9-15(2003).

Ward, G.S., G.C. Gram, P.R. Parrish, H. Trachman and A. Slesinger: Bioaccumulation and chronic toxicity of bis (tri-butyltin) oxide (TBTO): Test with a salt water fish. In: Aquatic Toxicology and Hazard Assessment: Fourth Conference, American Society for Testing and Materials (Eds.: D. R. Dickson and K. L. Dickson). ASTM STP737, p. 183-200 (1981).

Wilson, E. and N. Hansson: Problemet med marin påväxtochdesslös ningar (2015). 